Article

\title{
Promoting the Sustainability of Organizations: Contribution of Transformational Leadership to Job Engagement
}

\author{
Guadalupe Vila-Vázquez *(i), Carmen Castro-Casal ${ }^{\circledR}$, Dolores Álvarez-Pérez and \\ Luisa del Río-Araújo
}

Department of Business Administration and Marketing, Facultade de Ciencias Económicas e Empresariais, Universidade de Santiago de Compostela, Avda. do Burgo, s/n. Campus Norte, 15782 Santiago de Compostela, Spain; carmela.castro.casal@usc.es (C.C.-C.); mdolores.alvarez@usc.es (D.Á.-P.); marisa.delrio@usc.es (L.d.R.-A.)

* Correspondence: guadalupe.vila@usc.es; Tel.: +34-981-563-100

Received: 19 September 2018; Accepted: 6 November 2018; Published: 9 November 2018

check for updates

\begin{abstract}
The psychology of sustainability highlights the importance of building organizational environments promoting the employees' well-being, and leaders play an important role in it. Drawing from Kahn's theory, the purpose of this study is to simultaneously examine the mediating role of task significance, perceived organizational support (POS) and employees' core self-evaluations (CSE) in the relationship between supervisors' transformational leadership and job engagement. In order to test the proposed model, a structural equation modelling was performed using the bootstrapping technique in IBM SPSS Amos 23 for Windows. The sample consisted of 320 employees from emergent high-tech and knowledge-based SMEs in Spain. The results supported all the hypotheses posited. By helping employees to find the meaning and significance of their work, making them feel supported by the organization and strengthening their sense of worth and competence, transformational leaders boost job engagement, a key aspect of the human dimension of organizational sustainability. This paper contributes to the psychology of sustainability by advancing knowledge of the mechanisms through which supervisors' transformational leadership influences employees' well-being in terms of job engagement.
\end{abstract}

Keywords: psychology of sustainability; leadership; job engagement; task significance; perceived organizational support; core-self evaluations

\section{Introduction}

The psychology of sustainability considers sustainability in broad terms, encompassing not only economic, ecological and social factors, but also the well-being and quality of life from a preventive approach [1,2]. Leadership styles focused on values, respect, dignified treatment and support contribute to employee well-being and sustainable development in organizations $[1,3]$. Although researchers have analyzed the direct and indirect effect of transformational leadership on various indicators of the followers' well-being [4-6], few studies have tested several mediators simultaneously. In this sense, recently, Arnold [7] has called for new studies analysing simultaneously multiple mediating variables in this relationship and "determine which mediators are key in explaining this relationship" (p. 389).

There is no commonly accepted definition of well-being. From a broad perspective, well-being is a "mental, physical and general health state of individuals, as well as their experiences of satisfaction both at work and outside of work" [8] (p. 104). In fact, well-being has been conceptualized in various ways according to the specific purpose of the research, covering both physical and psychological health, 
and measured in negative (e.g., stress, burnout, or emotional exhaustion) and in positive (e.g., affect, affective well-being, engagement, among others) (see the reviews by Arnold [7] and Nielsen et al. [8]).

Engagement is a psychological affective-motivational state characterized by high pleasure and high activation. Engaged employees manifest positive emotions (excitement, enthusiasm, energy) [9]. While in some studies it has been considered as an indicator of well-being (e.g., Schaufeli et al. [10] and Mäkikangas et al. [11]), in others it has been treated as a predictor of employee's well-being and general health (e.g., Shimazu et al. [12] and Caesens et al. [13]).

The aim of this study is to examine the underlying processes through which transformational leadership increases individual well-being in terms of job engagement, in a technological and knowledge-intensive context.

Kahn [14] defined engagement as "the simultaneous employment and expression of a person's 'preferred self' in task behaviors that promote connections to work and to others, personal presence (physical, cognitive, and emotional) and active, full performances" (p. 700). Engaged employees enjoy better health and well-being. Longitudinal research confirms that engagement leads, over time, to an improvement in employee health and an increase in satisfaction with life [12,15]. Job engagement predicts higher employee performance and citizenship behaviors [16], as well as knowledge-sharing and innovative behavior [17,18]. In addition, collective engagement has been found to positively influence firm performance [19]. Consequently, engagement promotes not only social sustainability if not also organizational development and economic sustainability. Indeed, it has been argued that employees' engagement enables organizations to develop and maintain a competitive advantage $[9,20]$, contributing to their long-term success and competitiveness [21] and their sustainability [17,22].

Leadership is recognized as a determinant of employee health and well-being. Nevertheless, according to Wegge et al. [3], the underlying processes are not fully understood. Research has supported the positive effect of health-promoting leadership and transformational leadership on employees' well-being, and on their engagement in particular [23-27]. Transactional leadership has a lower motivational power [28] and lacks the inspirational attractive of transformational leadership [29]. The recent meta-analytic review by Hoch et al. [30] documented a strong corrected correlation $(\rho=0.48)$ between transformational leadership and engagement. Despite this, further studies are needed to analyze the mechanisms intervening in the association between transformational leadership and employee job engagement [23,31,32].

According to Saks and Gruman [33], the transformational leadership can indirectly influence followers' engagement by providing them with the necessary resources to perform their work. These, in turn, will generate states of greater psychological meaningfulness ("sense of return on investments of self in role performance" [14] (p. 705)), safety ("sense of being able to show and employ self without fear of negative consequences to self-image, status or career" [14] (p. 705)) and availability ("sense of possessing the physical, emotional, and psychological resources necessary for investing self in role performances" [14] (p. 705)) that will boost employees to invest their entire self in their work role. Drawing from Kahn's theory, Rich et al. [9] argued that perceptions of task factors and social systems related to support are the main determinants of psychological meaningfulness and safety, respectively, and the subsequent engagement level. They also suggested that the evaluations that individuals make of their self-worth, competencies, and abilities largely determine their psychological availability.

Based on these assumptions, this research proposes that perceived task significance, perceived organizational support (POS) and employees' core self-evaluations (CSE) will mediate the effect of the supervisor's transformational leadership on the employees' engagement. First, because the leader frames the 'reality' in which employees perform their jobs [34] (p. 327), he/she can generate in followers the perception that the tasks they perform are significant. Second, transformational leaders are concerned with the needs and well-being of the followers [35]. To the extent that employees often attribute the actions carried out by the immediate manager to the organization itself [36], supervisors' transformational leadership can be expected to foster a greater POS. Third, because transformational 
leaders can influence the sense of worth and confidence of followers [37], they are expected to positively influence employees' CSE.

In his study, Kahn [14] highlighted the potential of tasks characteristics as key antecedents of psychological meaningfulness and subsequent engagement. Tasks significance refers to "the degree to which a job influences the lives or work of others" [38] (p. 1323). Several reasons have guided the choice of this job dimension. On the one hand, it is the job characteristic that most consistently predicts the meaningfulness experienced in work [39,40]. The recent longitudinal research by Allan [40] shows that task significance predicts the work significance over time. On the other, according to Grant [41], to the extent that workers are increasingly interested in the contribution of their work to others and society, it is a key aspect of work experiences in the current economy. However, only two studies $[42,43]$ have investigated the effect of task significance on job engagement. Furthermore, while the relationship between transformational leadership and job characteristics is well documented [34,44,45], almost all studies have used an aggregate measure.

Kahn [14] considered supportive and trusting relationships and supportive management as precursors of engagement, because of their impact on psychological safety. POS refers to employees' "global beliefs concerning the extent to which the organization values their contributions and cares about their well-being" [36] (p. 501). POS, together with trust in the organization, is a key precursor to the safety experienced by employees, both individually and collectively [46]. Responding to Eisenberger and Stinglhamber's [47] call for more research on the effect of POS on job engagement, recent studies have provided evidence of this relationship (e.g., Brunetto et al. [48] and Zhong et al. [49]). However, to the best of our knowledge, no study has analyzed the POS as a mediator in the transformational leadership-job engagement relationship.

For employees to be willing to bring their full selves into the role they need to feel that they have the necessary psychological resources $[9,14]$. Personal resources, such as CSE, favor psychological availability [33]. CSE refers to the "fundamental appraisal of one's worthiness, effectiveness, and capability as a person" [50] (p. 304). Several studies have found a positive impact of employee's CSE on job engagement. In addition, it has been suggested that leadership can influence follower's self-concept [51]. In this sense, Zhou and Wu [52] corroborated that humble leadership enhanced the CSE of employees working at technological firms in China. However, we are unaware of any study that has explored the mediating role of CSE in the relationship between transformational leadership and job engagement.

In summary, this paper contributes to the psychology of sustainability by advancing knowledge of the mechanisms through which supervisors' transformational leadership influences employees' well-being, in terms of job engagement. At the same time, drawing from the theoretical framework proposed by Kahn [14], it provides evidence of the determinants of job engagement in a context of emergent high-tech and knowledge-based SMEs in Spain. These firms constitute the basis of the current economic development [53] and contribute to the innovation and development of the regions [54-56].

\section{Theoretical Framework}

Kahn's theory [14] asserts that engagement depends on three psychological states: Meaningfulness, safety and availability. These conditions, in turn, are affected by people's perceptions of work contexts and their personal resources. In this study, the indirect effect of transformational leadership on employee job engagement is explained via three focal factors: Task significance (meaningfulness), POS (safety) and CSE (availability). As explained previously, each of the mediating variables considered represents a key determinant of these psychological states $[9,40,46,57]$.

\subsection{Task Significance as Mediator}

According to Kahn's theory [14], people's job perceptions influence the psychological work experience. Employees in enriched jobs will experience more psychological meaningfulness (i.e., they will feel useful and valuable) and engagement $[14,43,57]$. When employees believe that 
the tasks performed are significant, they will be willing to invest their entire self in their job [14,57], to devote more time and energy [41] and to maintain it, even in the face of difficulties [43]. Grant [58] theorized that the likelihood that employees will invest more effort and be more persistent in completing tasks increases if they are aware of the impact of their work on others. Two empirical studies $[42,43]$ have supported the influence of task significance on job engagement. Furthermore, Christian et al.'s meta-analysis [59] provided evidence of a strong positive correlation between these variables.

On the other hand, it is assumed that transformational leaders can affect employees' perceptions of work $[34,41,60]$. Apart from making changes in the content of the job, leaders, as potential sources of social information, can significantly influence employees' perceptions of the job importance [61].

Cleavenger and Munyon argue that by using "words, actions and/or symbols when talking about work" [60] (p. 352), transformational leaders frame job experiences and strengthen the perceptions of significance and meaning that employees attribute to their work. Piccolo and Colquitt [34] affirmed that transformational leaders, by expressing with clarity an irresistible shared vision and highlighting the effects of work decisions from an ethical and moral point of view, encourage employees to perceive their work as more important and self-congruent. According to Bass [62] and Shamir et al. [37], transformational leaders boost the follower's perception of the importance to their job. Purvanova et al. [44] concluded that employees whose managers were engaged in transformational behaviors considered their jobs to be more significant and challenging. When leaders emphasize the relevance of the employees' contributions to the organization and its mission, and link them to a broader purpose, the perceptions of the task significance will increase $[44,60]$. Several studies support that transformational leadership positively affects employees' perception of job characteristics evaluated in the aggregate [34,44,45]. Additionally, the studies by Aryee et al. [23] and Ghadi et al. [26] suggest that transformational leaders influence employee engagement by encouraging employees to perceive meaning in work. Recent evidence indicates that other job motivational characteristics, such as autonomy, mediate the transformational leadership-engagement relationship [28,63].

According to the previous arguments, it is expected that perceived task significance explains the indirect effect of transformational leadership on job engagement.

Hypothesis 1. Transformational leadership is indirectly related to job engagement via task significance.

\subsection{POS as Mediator}

From Kahn's perspective [14], POS is a key determinant of psychological safety [46]. Employees perceiving high organizational support will consider their work environment as safer and more reliable and, as a result, will have little reason to fear negative consequences that could damage their "self-image, status, or career" [14] (p. 708), because of investing their energies in the work role $[9,64]$. In addition, POS strengthens employees' expectations of effort and reward [65]. POS provides some assurance to employees that the organization will respond with favorable treatment to their efforts and investments to help it achieve their objectives. According to Kahn [66], engagement requires that employees have a clear sense of the relationship between their efforts and results. Employees perceiving high organizational support will be willing to intensify their efforts and invest all their energies in their role because they anticipate being recognized.

Drawing from social exchange theory [67], Saks [68] noted that employees believing that the organization is concerned by them and take care of their well-being try to balance their relationship with the organization. In this situation, employees will develop favorable attitudes and behaviors consistent with the perceived support and will increase their level of job engagement. Previous research has supported the influence of POS on job engagement $[9,48,49,68]$.

Furthermore, it has been argued that the actions of managers and supervisors are often attributed to the organization itself [36]. The flat structure that characterizes SMEs promotes that 
employees "identify their supervisors more with the organization's basic character than those in large organizations" [69] (p. 572). Therefore, it is to be expected that the support, caring and recognition actions carried out by the transformational supervisors will be attributed to the organization.

Transformational leaders articulate a shared vision and express high expectations that motivate, inspire and challenge followers [70]. As a result, it provides followers with purpose and effectiveness and thus with positive assessments of their contributions to the organization [35,47]. Transformational leaders recognize the employees' needs and abilities, treat them as unique individuals, and build individualized relationships with them [62]. These behaviors, which convey care, recognition and appreciation, and improve the employee's subjective well-being, foster POS [35]. Transformational leaders are concerned with improving the knowledge, skills and abilities of followers and empowering them by involving them in decision making [70]. With all these behaviors, the leader transmits that the organization is favorably oriented toward employees. Recent research corroborates the role of the supervisor's positive leadership styles, such as transformational leadership, in creating a supportive context aimed at generating a psychologically safe environment [46].

Based on the above arguments, it is to be expected that:

Hypothesis 2. Transformational leadership is indirectly related to job engagement via POS.

\subsection{CSE as Mediator}

Kahn $[14,66]$ argued that to put all their energies into their job and be able to express their true self, people need to feel having the necessary personal resources. People with high CSE are adaptable, positive, confident, and effective, and believe in their own agency [50]. In addition, people with high CSE assess demands more positively and feel that they are better able to meet them effectively [50,71]. In short, they will perceive that they have more resources to invest themselves in their job.

The approach/avoidance framework [72] suggests that differences in people's sensitivity to positive and negative information are what drives the relationship between CSE and results. Ferris et al. [73] and Aryee et al. [74] confirmed that people with high CSE were more likely to adopt a motivational orientation toward positive stimuli and less likely to adopt negative stimuli. As a result, employees with high CSE are more likely to feel autonomous in pursuing positive work outcomes and to consider themselves more competent than those with low CSE [75]. The studies by Karatepe and Demir [76] and Lee and Ok [77] corroborated the positive effect of CSE on job engagement in samples of hotel sector employees. Rich et al. [9] achieved at the same result in a sample of firefighters.

Furthermore, both transformational leadership theory [62] and self-concept based leadership theory [37] emphasize that one of the main objectives of transformational leaders is to enhance the followers' sense of self-worth and self-concept. By delegating responsibilities to employees, transformational leaders not only contribute to them acquiring new skills [70], they also express confidence in their competencies and reinforce their feelings of personal worth. According to de Cremer et al. [78], leaders empowering their followers, such as transformational leaders, improve their self-confidence and, thus, their self-concept.

Transformational leaders enhance the followers' self-esteem and self-efficacy by expressing high expectations, trusting in their abilities to meet these expectations, showing how the organization's mission reflects their personal values and emphasizing the relationships between efforts and important results [37]. Kark et al. [79] showed that transformational leadership was positively related to followers' organization-based self-esteem in a sample of employees working for a bank in Israel. Research has also found a positive influence of transformational leadership on the followers' self-efficacy [79-81]. Nielsen et al. [6] supported that the individual self-efficacy completely mediated the effect of transformational leadership on the well-being of the cared employees. 
Research supports that personal resources and CSE are influenced, at least in part, by other contextual factors. For example, Xanthopoulou et al. [82] discovered that autonomy, peer support, supervisory coaching and opportunities for professional development stimulated employees' personal resources, operationalized as generalized self-efficacy, organizational-based self-esteem and optimism, which in turn generated more engagement and less exhaustion. Karatepe et al. [83] confirmed that employees with more coworker support reported higher CSE and that these, in turn, significantly impacted on vigor and dedication, two dimensions of engagement. Nguyen and Borteyrou [84] found that person-environment fit indirectly influenced job satisfaction through the CSE, and Liu et al. [85] analyzed the mediating role of CSE in the relationship between social support and well-being.

Based on the aforementioned arguments and available evidence, transformational leadership is likely to have an indirect positive effect on job engagement via CSE. Consequently, it is proposed the following:

Hypothesis 3. Transformational leadership is indirectly related to job engagement via CSE.

\section{Method}

\subsection{Sample}

Data were gathered from a sample of employees from emergent high-tech and knowledge-based SMEs in Spain. One hundred SMEs, operating for 10 or fewer years [40] in high-tech and knowledge intensive industries according to Eurostat classification, were contacted to collaborate in the study. Ultimately, 21 firms, sizing between 10 and 100 employees, agreed to participate.

Management provided the research team with the employees' emails. A questionnaire link was mailed directly to the employees to guaranty anonymity. Of the 443 questionnaires distributed, 320 were returned. The response rate per firm ranged from $41.0 \%$ to $92.9 \%$. The average response rate was $68.98 \%$ in medium-sized firms (169 responses from 245 questionnaires distributed) and $76.26 \%$ in small firms (151 responses from 198 questionnaires distributed).

Respondents' mean age was 32.09 years $(\mathrm{SD}=6.18)$, and $204(63.75 \%)$ were men. With regard to education level, $69.06 \%$ held a higher education degree, $27.81 \%$ held a master or a $\mathrm{PhD}$ degree, and $3.12 \%$ had high school education or below.

\subsection{Measures}

All the variables were measured using a seven-point Likert scale $(1=$ strongly disagree, 7 = strongly agree) and taken or adapted from previously validated and published instruments. Because the scales were originally written in English, they were subjected to a translation process following the procedure proposed by Brislin [86].

Transformational leadership was assessed with the seven-item Global Transformational Leadership (GTL) measure proposed by Carless et al. [70]. An example item is "My supervisor treats staff as individuals, supports and encourages their development".

Task significance was assessed with three items of the Work Design Questionnaire (WDQ) by Morgeson and Humprey [38]. An example is "The results of my work are likely to significantly affect the lives of other people".

POS was measured with six items of the Survey of Perceived Organizational Support by Eisenberger et al. [36]. To improve the participants' understanding, one reverse score item was worded positively. An example item is "The organization really cares about my well-being".

CSE was assessed with the twelve-item Core Self-Evaluations Scale (CSES) by Judge et al. [50]. An example item is "I am filled with doubts about my competence" (reverse item).

Job engagement was measured with Rich et al.'s scale [9] based on Kahn's conceptualization. This scale is composed of three dimensions: Physical (e.g., "I devote a lot of energy to my job"), 
emotional (e.g., "I am enthusiastic in my job"), and cognitive (e.g., "At work, I focus a great deal of attention on my job"). The four items with the highest factor loadings for each dimension were used.

As in previous engagement studies [23,49,87], age, gender and tenure were included as control variables.

\subsection{Analytical Methods}

Data analysis was carried out in two steps. First, a confirmatory factorial analysis was performed to analyze the fit of the measurement model and examine the internal consistency of each construct, the convergent validity of the scales and the discriminant validity of the constructs. Then, the structural model was estimated using latent structural equation modelling. To analyze mediation, the initially hypothesized model was compared with alternative models. The analyses were performed with IBM SPSS Amos 23 for Windows.

The bootstrapping technique was used to analyze the indirect effects. In the present study, a $95 \%$ confidence interval of indirect effect was calculated based on 2000 bootstrap resamples. Furthermore, to correct the instability of the parameters, due to the length of the CSE measurement, three parcels of four randomly selected items were created [88].

\section{Results}

The descriptive statistics and correlations are displayed in Table 1. As is shown, the correlations were aligned with the hypotheses.

Table 1. Descriptive statistics, correlations, and reliability coefficients.

\begin{tabular}{lcccccccccc}
\hline \multicolumn{1}{c}{ Variable } & $\mathbf{M}$ & SD & $\mathbf{1}$ & $\mathbf{2}$ & $\mathbf{3}$ & $\mathbf{4}$ & $\mathbf{5}$ & $\mathbf{6}$ & $\mathbf{7}$ & $\mathbf{8}$ \\
\hline 1. Gender & - & - & & & & & & & \\
2. Age & 32.09 & 6.18 & -0.09 & & & & & \\
3. Tenure & 3.17 & 2.52 & $-0.18^{*}$ & $0.37^{* * *}$ & & & & & \\
4. Transformational leadership & 5.25 & 1.43 & -0.06 & $-0.20^{* * *}$ & $-0.16^{* *}$ & $(0.96)$ & & \\
5. Task significance & 4.71 & 1.30 & -0.00 & 0.10 & -0.02 & $0.14^{*}$ & $(0.81)$ & & \\
6. Perceived organizational support & 4.73 & 1.46 & 0.04 & -0.02 & $-0.19^{* * *}$ & $0.57^{* * *}$ & $0.28^{* * *}$ & $(0.96)$ & \\
7. Core-self evaluations & 5.30 & 0.82 & -0.03 & $-0.13^{*}$ & 0.00 & $0.37^{* * *}$ & $0.32^{* * *}$ & $0.25^{* * *}$ & $(0.82)$ & \\
8. Job engagement & 5.77 & 0.82 & 0.11 & 0.05 & -0.08 & $0.33^{* * *}$ & $0.49^{* * *}$ & $0.44^{* * *}$ & $0.56^{* * *}$ & $(0.93)$ \\
\hline
\end{tabular}

Note. $\mathrm{N}=320$. Values in parentheses are Cronbach's alphas. ${ }^{*} p<0.05,{ }^{* *} p<0.01,{ }^{* * *} p<0.001$.

To confirm the constructs' reliability and validity, prior to testing the hypotheses, we conducted CFAs. First, to evaluate the second-order structure of the engagement several models were proposed and compared. As can be seen in Table 2, the one-factor model, in which the different items were loaded into a single latent variable, adjusted poorly to the data. The three-factor model fitted significantly better than the one-factor model $\left(\chi^{2}(3)=723.382, p<0.001\right)$. The high correlations [89] between the three dimensions of engagement (mean correlation $=0.655$ ) suggest a commonality indicative of a higher order factor $[9,87,90]$. Therefore, an additional model reflecting a second-order factor structure was estimated. This model has the same fit statistics than the three-factor model, since the number of estimated relationships and degrees of freedom are the same [9]. Furthermore, the second-order factorial loads of the three dimensions $(0.879,0.690$ and 0.866$)$ are all positive, high and statistically significant, supporting the structure as second-order factor [9].

Table 2. Engagement structure.

\begin{tabular}{ccccccc}
\hline Models & $\chi^{\mathbf{2}}$ & df & CFI & IFI & RMSEA & CI 90\% RMSEA \\
\hline One-factor structure & 842.983 & 52 & 0.764 & 0.765 & 0.218 & $0.206-0.231$ \\
Three-factor structure & 119.601 & 49 & 0.979 & 0.979 & 0.067 & $0.052-0.083$ \\
Second-order structure & 119.601 & 49 & 0.979 & 0.979 & 0.067 & $0.052-0.083$ \\
\hline
\end{tabular}

Note. $\mathrm{N}=320$. In the three models, it was allowed error variances for two items of the physical dimension and other two of the emotional one to correlate. 
Second, the measurement model fit was tested. The results indicated an adequate fit with the data $\left(\chi^{2}(421)=1048.853 ; \chi^{2} / \mathrm{df}=2.491 ; \mathrm{CFI}=0.934 ; \mathrm{TLI}=0.928 ; \mathrm{RMSEA}=0.068\right)$, implying the acceptability of the proposed model.

Table 3 summarizes the statistics used to verify the scales' reliability and validity. The composite reliability (CR) and the average variance extracted (AVE) of each scale exceeded the established minimum of 0.6 and 0.5 , respectively [91], supporting the reliability of the scales. Convergent validity was evidenced by verifying that all the factor loadings were significant and higher than 0.5 . The discriminant validity between constructs was verified since the correlation confidence intervals excluded the unit value, and their squared correlations were lower than the AVE [91].

Table 3. Overall reliability and validity of the constructs.

\begin{tabular}{cccccc}
\hline & TL & TS & POS & CSE & JE \\
\hline \multirow{2}{*}{ TL } & CR $=0.964$ & & & & \\
& $\mathrm{AVE}=0.792$ & & & & \\
\hline \multirow{2}{*}{$\mathrm{TS}$} & $\mathrm{SC}=0.019$ & $\mathrm{CR}=0.818$ & & & \\
& $(0.008 ; 0.266)$ & $\mathrm{AVE}=0.600$ & & & \\
\hline \multirow{2}{*}{ POS } & $\mathrm{SC}=0.328$ & $\mathrm{SC}=0.080$ & $\mathrm{CR}=0.959$ & & \\
& $(0.467 ; 0.679)$ & $(0.157 ; 0.407)$ & $\mathrm{AVE}=0.797$ & & \\
\hline \multirow{2}{*}{$\mathrm{CSE}$} & $\mathrm{SC}=0.134$ & $\mathrm{SC}=0.100$ & $\mathrm{SC}=0.063$ & $\mathrm{CR}=0.824$ & \\
& $(0.244 ; 0.488)$ & $(0.176 ; 0.458)$ & $(0.123 ; 0.377)$ & $\mathrm{AVE}=0.610$ & \\
\hline \multirow{2}{*}{$\mathrm{JE}$} & $\mathrm{SC}=0.111$ & $\mathrm{SC}=0.236$ & $\mathrm{SC}=0.194$ & $\mathrm{SC}=0.316$ & $\mathrm{CR}=0.855$ \\
& $(0.213 ; 0.453)$ & $(0.363 ; 0.609)$ & $(0.333 ; 0.549)$ & $(0.446 ; 0.678)$ & $\mathrm{AVE}=0.664$ \\
\hline
\end{tabular}

Note. TL, transformational leadership; TS, task significance; POS, perceived organizational support; CSE, core-self evaluations; JE, job engagement; $\mathrm{CR}$, composite reliability; AVE, average variance extracted; $\mathrm{SC}$, squared correlation.

All the data were collected from a single source. Therefore, to examine the influence of common method bias, Harman's one-factor test using a CFA [92] was applied. The model in which all the items of the five variables loaded onto the same factor did not fit the data well $\left(\chi^{2}(435)=6095.668\right.$; $\chi^{2} / \mathrm{df}=14.013 ; \mathrm{CFI}=0.409 ; \mathrm{TLI}=0.386 ;$ RMSEA $\left.=0.202\right)$, suggesting that common method bias was not a significant issue in the present study [92].

The results of the structural model suggest that the hypothesized model (HM) provides good fit with the data $\left(\chi^{2}(425)=1081.935 ; \chi^{2} / \mathrm{df}=1.923 ; \mathrm{CFI}=0.931 ; \mathrm{IFI}=0.932\right.$; $\left.\mathrm{RMSEA}=0.070\right)$. Based on existing theory, alternative models were considered to determine which of these best fit the data. The comparison models were based on the saturated model, which coincides with a partial mediation model. Four alternative models were then proposed. In the first one (M1), only the direct relationships of each variable with the dependent variable were considered. In the following ones, the relationships of transformational leadership with each of the mediating variables were eliminated (M2, with no transformational leadership-task significance relationship; M3, with no transformational leadership-POS relationship; and M4, with no transformational leadership-CSE relationship).

Following the Hair et al.'s [91] recommendation, to determine the best model, differences in $\chi^{2}$ were established according to the degrees of freedom. As can be seen in Table 4, the hypothesized model (HM: Total mediation) is the one that presents a significantly better fit. 
Table 4. Model comparison.

\begin{tabular}{cccccccccc}
\hline Models & $\chi^{2}$ & df & CFI & IFI & RMSEA & CI 90\% RMSEA & $\Delta \chi^{2}$ & df & $p$ \\
\hline Partial mediation & 1081.833 & 424 & 0.931 & 0.932 & 0.070 & $0.065-0.075$ & & & \\
Hypothesized model & 1081.935 & 425 & 0.931 & 0.932 & 0.070 & $0.064-0.075$ & 0.102 & 1 & ns \\
(HM): total mediation & 1240.245 & 427 & 0.915 & 0.915 & 0.077 & $0.072-0.082$ & 158.412 & 3 & $<0.001$ \\
M1 & 1086.872 & 425 & 0.931 & 0.931 & 0.070 & $0.065-0.075$ & 5.039 & 1 & $<0.05$ \\
M2 & 1199.399 & 425 & 0.919 & 0.919 & 0.076 & $0.071-0.081$ & 117.566 & 1 & $<0.001$ \\
M3 & 1118.409 & 425 & 0.928 & 0.928 & 0.072 & $0.066-0.077$ & 36.576 & 1 & $<0.001$ \\
M4 & &
\end{tabular}

Note. M1: Only the direct relationships of each variable with the dependent variable were considered; M2: With no transformational leadership-task significance relationship; M3: With no transformational leadership-POS relationship; M4: With no transformational leadership-CSE relationship.

Figure 1 shows the parameters of the structural model.

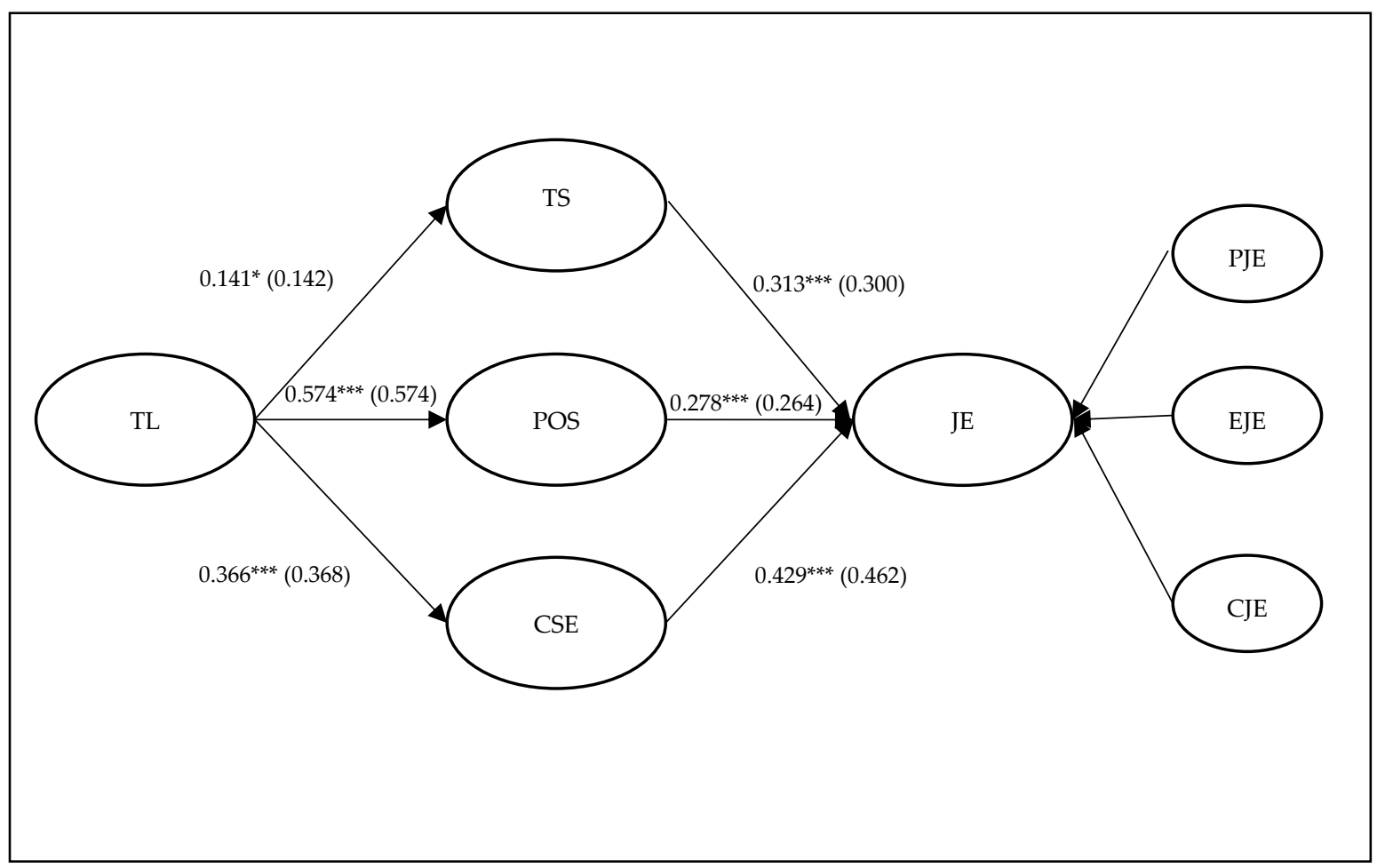

Figure 1. Structural model. ${ }^{*} p<0.05,{ }^{* *} p<0.01,{ }^{* * *} p<0.001$. Note. TL, transformational leadership; TS, task significance; POS, perceived organizational support; CSE, core-self evaluations; $\mathrm{JE}$, job engagement; PJE, physical job engagement dimension; EJE, emotional job engagement dimension; CJE, cognitive job engagement dimension. Values in parentheses are the parameters of the structural model, including the control variables.

To test the mediation hypotheses, the bootstrapping technique was used. As can be seen in Table 5, the 95\% confidence intervals (CI) for the indirect effects of transformational leadership on job engagement via task significance, POS and CSE exclude zero. These results provide support for Hypotheses 1-3 and confirm the indirect effect of transformational leadership on job engagement through the three considered variables. Together, the independent and mediating variables explain $43.8 \%$ of the variance in job engagement. 
Table 5. Indirect effects of transformational leadership on job engagement.

\begin{tabular}{ccccc}
\hline Indirect Effects TL $\rightarrow$ VM $\rightarrow$ JE & Estimate & 95\% CI (Lower) & 95\% CI (Upper) & $p$ \\
\hline $\mathrm{H} 1: \mathrm{TL} \rightarrow \mathrm{TS} \rightarrow \mathrm{JE}$ & 0.029 & 0.004 & 0.066 & 0.026 \\
$\mathrm{H} 2: \mathrm{TL} \rightarrow \mathrm{POS} \rightarrow \mathrm{JE}$ & 0.106 & 0.059 & 0.170 & 0.001 \\
$\mathrm{H} 3: \mathrm{TL} \rightarrow \mathrm{CSE} \rightarrow \mathrm{JE}$ & 0.104 & 0.059 & 0.162 & 0.001 \\
\hline
\end{tabular}

Note. TL, transformational leadership; VM, mediating variable; JE, job engagement; TS, task significance; POS, perceived organizational support; CSE, core-self evaluations.

\section{Discussion and Implications}

To encourage employees' job engagement is considered essential to the sustainability of organizations [17,22] and for their survival and long-term success [20,21], particularly in those immersed in a changing environment [93]. Emergent high-tech and knowledge-based SMEs "are the foundation for economic growth in today's business" [53] (p. 241). Their development and sustainability depend to a large extent on using and developing employee's talent, encouraging their well-being and stimulating them to give their best.

The purpose of this paper is to improve the understanding of the mechanisms through which supervisors' transformational leadership influences job engagement. In particular, this paper explores the mediating role of perceived task significance, POS and employees' CSE in the transformational leadership-job engagement relationship in the context of emergent high-tech and knowledge-based SMEs.

This study shows that supervisors' transformational leadership influences job engagement by framing followers work to help them to find meaning and significance into the tasks they perform (Hypothesis 1). When employees perceive that their job tasks have a substantial influence on the life or work of others, a sense of meaningfulness is generated. This sense increases their willingness to invest their complete self and channel all their energies (physical, emotional and cognitive) into the work role [14]. It is displayed, therefore, that the transformational leadership models the employees' perceptions about their work [61], generating significant work experiences.

Moreover, transformational supervisors foster the belief that the organization values followers' contributions and cares about their well-being. Transformational leadership has been associated with the perception of more support from the supervisor [94] strongly linked to POS [35,69]. In line with the results of research undertaken in other contexts $[9,48,49,68]$, it is supported that the POS positively influences job engagement. Recently, Caesen et al. [13] discovered that weekly POS positively influenced weekly engagement and subsequent subjective well-being.

Employees who perceive a supportive and trusting work environment are willing to invest and express their true self in their jobs, because they feel psychologically more secure and are not afraid of negative consequences [14,46,64]. This finding is consistent with Kahn's theory [14] and organizational support theory $[36,47]$. Therefore, this research supports the indirect effect of transformational leadership on employees' job engagement via POS (Hypothesis 2). This is in accordance with the results of Breevaart et al.'s [28] daily study, in which the authors found that when leaders showed a more transformational behavior, followers perceived more social support, this, in turn, boosted their engagement.

While some studies have demonstrated the influence of other leadership styles (e.g., humble leadership) on followers' CSE [52], to our best knowledge, this is the first study to corroborate that the transformational leadership arouses employees' engagement by enhancing the followers' CSE (Hypothesis 3). On one hand, in consonance with the transformational leadership theory [62] and the self-concept based leadership theory [37], the results indicate that transformational supervisors enhance the followers' sense of self-worth and self-concept. On the other hand, in agreement with Kahn's theory [14], employees with high CSE feel psychologically available to invest their entire self in the work, i.e., they feel energetic, emotionally linked to and happily absorbed in their works. 
An interesting result is derived from the relative strength of the indirect effects of transformational leadership on job engagement. The strongest indirect effects are through POS and CSE. The indirect effect via task significance, although significant, is somewhat less than one would expect. This result may be due to the fact that employees perceive the task significance both on the basis of the job and the social context cues (namely, transformational leadership) [34,58].

The context of this research (emergent high-tech and knowledge-based SMEs) could also have influenced. In these firms, characterized by flat structures and project-based work, employees perform multiple roles [95] and interdependent tasks [93] that can generate the perception of task significance [96]. Furthermore, their size and age could also make it easier for employees to better see the link between their work and the firm's purpose and vision.

It has been argued that psychological safety may be more important for engagement in contexts in which employees perform "complex, uncertain, creative tasks" [57] (p. 31), as emergent high-tech and knowledge-based SMEs [97]. In this context, supervisor transformational leadership can contribute to increase predictability, while generating a non-threatening environment in which employees can try and experiment and put all their energies into creative work. Finally, feelings of competence and worth are necessary to deal with the challenging demands derived from complexity and uncertainty [71].

On the other hand, it is possible that the different dimensions of transformational leadership (idealized influence, inspirational motivation, individualized consideration, intellectual stimulation, [62]) have differential effects on the perceptions of task significance, POS and CSE. For example, one might expect that when leaders engage in behaviors of idealized influence and inspirational motivation, employees will perceive that their work is more meaningful. Individualized consideration could be associated more strongly with the perception of support, and the inspirational motivation and intellectual stimulation with CSE [98]. Given that the scale used in this study is one-dimensional in nature, it does not allow us to assess it. We believe that it would be interesting to analyze it in future researches.

In sum, the results indicate that the transformational supervisors indirectly influence followers' job engagement through three avenues: Helping them to find that the tasks they perform are significant and have meaning, making them feel supported by the organization, and improving their sense of worth and competence. In terms of psychological states, transformational leadership favors the psychological meaningfulness, safety and availability [14] required for employees to decide to put their hands, mind and heart into their jobs [9]. It represents an important advance in the comprehension of the mechanisms involved in the complex relationship between transformational leadership and job engagement responding to the recent calls made by several scholars [7,23,31,32]; and it serves to enrich the debate on how the distinct forms of leader behavior could have a bearing on employee health and well-being [3].

It also supports the Saks and Gruman's theoretical approach [33] according to which the effect of transformational leadership on job engagement occurs through the contextual and personal resources perceived by employees. The results are also in line with the conservation of resources theory [99] which states that people try to conserve current resources and acquire new resources. Those individuals with a greater resource base are better able to invest resources, and as resources are gained, they can increase their investment to achieve additional resources. As defined by Hobfoll [99], resources are "those objects, personal characteristics, conditions, or energies that are valued by the individual or that serve as a means for attainment of these objects" (p. 516). From Halbesleben et al.'s perspective [100], the value of a resource for the individual will be greater to the extent that it helps him/her to achieve his/her goals. Since transformational leadership favors employees' access to valuable resources (that is, perceptions of task significance, organizational support, and feelings of competence and personal worth) that can help them to achieve their goals they will increase their investment in role, that is, they will simultaneously invest their physical, emotional and cognitive energies in their job.

The results of this study shed light on some interventions to increase employee well-being in terms of engagement. In order to create a healthy organizational environment promoting work 
meaning and safety, task significance and POS should be cultivated. Jobs could be designed so that employees perceive that the tasks they perform have a significant impact on others, and society [38]. Encouraging employees to have greater interaction with those they benefit will strengthen the significance they attach to their job $[41,58]$. To pay special attention to interpersonal relationships, establish two-way communication channels, and provide employees with the needed resources to perform their work $[13,35]$ are undoubtedly actions that contribute to POS. Our study suggests that supervisors should inspire and provide a purpose for employees, provide them support, involve them in decision making, encourage their creativity, and act as role models. With these behaviors, supervisors will make employees more aware of the significance of the task and feel more supported by the organization, promoting higher levels of engagement.

In addition, supervisors can help to create an environment conducive to the development and growth of followers by encouraging their learning, giving them the opportunity to perform tasks that generate mastery and competence experiences, and providing them positive feedback. With this, they will strengthen the followers CSE and their level of engagement, contributing to build healthy workplaces [2] and to sustain the organization [17,22].

Based on the evidence that transformational leadership improves the employees' engagement through the task significance, POS and CSE, management at high-tech and knowledge-intensive SMEs should promote this leadership style among their supervisors. Several studies (e.g., Antonakis et al. [101] and Barling et al. [102]) have shown the effectiveness of training programs for transformational leadership development. It is therefore recommended that training programs for transformational leadership development should be carried out.

Despite the important implications, this study is not without limitations. First, the cross-sectional design limits causal inferences. Additional studies with longitudinal data are needed to support the causality of the relations.

Second, this study used employee self-reports, which may result in common method bias. Although common method bias is rarely severe enough to jeopardize the validity of the results [103], the Podsakoff et al.'s [92] recommendations concerning the design of the questionnaire were followed to reduce this bias. In addition, the results of the Harman's one-factor test using a CFA was applied; and the results suggest that common method bias was not a significant issue in the present study [92].

Third, in this study, the one-dimensional GTL scale was used to measure transformational leadership. This scale, which has the advantage of its short length (7 items), is highly correlated with other established scales, such as the MLQ [70], and has shown reliability and validity [6]. To examine the differential effects of the different facets of transformational leadership on the mediating variables, new research based on multidimensional measures (such as the MLQ) is required.

This study examined the underlying mechanisms connecting transformational leadership with job engagement. Therefore, CSE were considered as a mediator. Previous research has also analyzed CSE as a mediator between resources and contextual variables, and employees' attitudes, engagement and well-being. However, there is also evidence of the moderating role of CSE. For example, Zhang et al. [104] found that CSE moderated the abusive supervision-intrinsic motivation relationship. A future line of interest would be to analyze whether CSE moderate the relationship between positive leadership styles (such as transformational leadership) and job engagement.

This research is focused on the individual level. An interesting line for future studies would be to combine different levels of analysis into a multilevel nature model.

This study is based on Kahn's theoretical framework [14]. As it has been pointed out throughout the paper, there are theoretical arguments and empirical evidence that support the choice of the variables and the relations proposed. However, we recognize that a more accurate validation of the theory should include psychological states. Future studies could expand our research testing the mediation of psychological states in the relationships between the mediating variables and job engagement. 
Despite these limitations, we believe that the results can help scholars and practitioners better understand how to cultivate an environment that nurtures the employees' enthusiasm, energy, and their connection with work. For Kim et al. [22]: "A pivotal mechanism for understanding the human dimension of sustainability is the ability for employees to thrive or be engaged in the workplace" (p. 631).

Author Contributions: Conceptualization, G.V.-V., C.C.-C. and D.Á.-P.; Formal analysis, G.V.-V. and L.d.R.-A.; Investigation, G.V.-V. and D.Á.-P.; Methodology, G.V.-V. and L.d.R.-A.; Writing-original draft, G.V.-V., C.C.-C. and D.Á.-P.; Writing-review and editing, C.C.-C.

Funding: This research received no external funding.

Conflicts of Interest: The authors declare no conflict of interest.

\section{References}

1. Di Fabio, A. The psychology of sustainability and sustainable development for well-being in organizations. Front. Psychol. 2017, 8, 1534. [CrossRef] [PubMed]

2. Di Fabio, A. Positive healthy organizations: Promoting well-being, meaningfulness, and sustainability in organizations. Front. Psychol. 2017, 8, 1938. [CrossRef] [PubMed]

3. Wegge, J.; Shemla, M.; Haslam, S.A. Leader behavior as a determinant of health at work: Specification and evidence of five key pathways. Ger. J. Hum. Resour. Manag. 2014, 28, 6-23. [CrossRef]

4. Arnold, K.A.; Turner, N.; Barling, J.; Kelloway, E.K.; McKee, M.C. Transformational leadership and psychological well-being. J. Occup. Health Psychol. 2007, 12, 193-203. [CrossRef] [PubMed]

5. Kelloway, E.K.; Turner, N.; Barling, J.; Loughlin, C. Transformational leadership and employee psychological well-being: The mediating role of employee trust in leadership. Work Stress 2012, 26, 39-55. [CrossRef]

6. Nielsen, K.; Yarker, J.; Randall, R.; Munir, F. The mediating effects of team and self-efficacy on the relationship between transformational leadership, and job satisfaction and psychological well-being in healthcare professionals: A cross-sectional questionnaire survey. Int. J. Nurs. Stud. 2009, 46, 1236-1244. [CrossRef] [PubMed]

7. Arnold, K.A. Transformational leadership and employee psychological well-being: A review and directions for future research. J. Occup. Health Psychol. 2017, 22, 381-393. [CrossRef] [PubMed]

8. Nielsen, K.; Nielsen, M.B.; Ogbonnaya, C.; Känsälä, M.; Saari, E.; Isaksson, K. Workplace resources to improve both employee well-being and performance: A systematic review and meta-analysis. Work Stress 2017, 31, 101-120. [CrossRef]

9. Rich, B.L.; Lepine, J.A.; Crawford, E.R. Job engagement: Antecedents and effects on job performance. Acad. Manag. J. 2010, 53, 617-635. [CrossRef]

10. Schaufeli, W.B.; Taris, T.W.; Rhenen, W.V. Workaholism, burnout and engagement: One of a kind or three different kinds of employee well-being? Appl. Psychol. 2008, 57, 173-203. [CrossRef]

11. Mäkikangas, A.; Feldt, T.; Kinnunen, U.; Mauno, S. Does Personality Matter? A Review of Individual Differences in Occupational Well-Being. In Advances in Positive Organizational Psychology; Bakker, A.B., Ed.; Emerald Group Publishing Limited: Bingley, UK, 2013; pp. 107-143, ISBN 978-1780520001.

12. Shimazu, A.; Schaufeli, W.B.; Kamiyama, K.; Kawakami, N. Workaholism vs. work engagement: The two different predictors of future well-being and performance. Int. J. Behav. Med. 2015, 22, 18-23. [CrossRef] [PubMed]

13. Caesens, G.; Stinglhamber, F.; Ohana, M. Perceived organizational support and well-being: A weekly study. J. Manag. Psychol. 2016, 31, 1214-1230. [CrossRef]

14. Kahn, W.A. Psychological conditions of personal engagement and disengagement at work. Acad. Manag. J. 1990, 33, 692-724. [CrossRef]

15. Hakanen, J.J.; Schaufeli, W.B. Do burnout and work engagement predict depressive symptoms and life satisfaction? A three-wave seven-year prospective study. J. Affect. Disord. 2012, 141, 415-424. [CrossRef] [PubMed]

16. Bailey, C.; Madden, A.; Alfes, K.; Fletcher, L. The meaning, antecedents and outcomes of employee engagement: A narrative synthesis. Int. J. Manag. Rev. 2017, 19, 31-53. [CrossRef] 
17. Kim, W.; Park, J. Examining structural relationships between work engagement, organizational procedural justice, knowledge sharing, and innovative work behavior for sustainable organizations. Sustainability 2017, 9, 205. [CrossRef]

18. Chen, Z.J.; Zhang, X.I.; Vogel, D. Exploring the underlying processes between conflict and knowledge sharing: A work-engagement perspective. J. Appl. Soc. Psychol. 2011, 41, 1005-1033. [CrossRef]

19. Barrick, M.R.; Thurgood, G.R.; Smith, T.A.; Courtright, S.H. Collective organizational engagement: Linking motivational antecedents, strategic implementation, and firm performance. Acad. Manag. J. 2015, 58, 111-135. [CrossRef]

20. Albrecht, S.L.; Bakker, A.B.; Gruman, J.A.; Macey, W.H.; Saks, A.M. Employee engagement, human resource management practices and competitive advantage. J. Organ. Eff. 2015, 2, 7-35. [CrossRef]

21. Gruman, J.A.; Saks, A.M. Performance management and employee engagement. Hum. Resour. Manag. Rev. 2011, 21, 123-136. [CrossRef]

22. Kim, W.; Khan, G.; Wood, J.; Mahmood, M. Employee engagement for sustainable organizations: Keyword analysis using social network analysis and burst detection approach. Sustainability 2016, 8, 631. [CrossRef]

23. Aryee, S.; Walumbwa, F.O.; Zhou, Q.; Hartnell, C.A. Transformational leadership, innovative behavior, and task performance: Test of mediation and moderation processes. Hum. Perform. 2012, 25, 1-25. [CrossRef]

24. Bui, H.T.M.; Zeng, Y.; Higgs, M. The role of person-job fit in the relationship between transformational leadership and job engagement. J. Manag. Psychol. 2017, 32, 373-386. [CrossRef]

25. Song, J.H.; Kolb, J.A.; Lee, U.H.; Kim, H.K. Role of transformational leadership in effective organizational knowledge creation practices: Mediating effects of employees' work engagement. Hum. Resour. Dev. Q. 2012, 23, 65-101. [CrossRef]

26. Yasin Ghadi, M.; Fernando, M.; Caputi, P. Transformational leadership and work engagement: The mediating effect of meaning in work. Leadersh. Org. Dev. J. 2013, 34, 532-550. [CrossRef]

27. Kopperud, K.H.; Martinsen, $\varnothing$.; Humborstad, S.I.W. Engaging leaders in the eyes of the beholder: On the relationship between transformational leadership, work engagement, service climate, and Self-Other agreement. J. Leadersh. Organ. Stud. 2014, 21, 29-42. [CrossRef]

28. Breevaart, K.; Bakker, A.; Hetland, J.; Demerouti, E.; Olsen, O.K.; Espevik, R. Daily transactional and transformational leadership and daily employee engagement. J. Occup. Organ. Psychol. 2014, 87, 138-157. [CrossRef]

29. Tims, M.; Bakker, A.B.; Xanthopoulou, D. Do transformational leaders enhance their followers' daily work engagement? Leadersh. Q. 2011, 22, 121-131. [CrossRef]

30. Hoch, J.E.; Bommer, W.H.; Dulebohn, J.H.; Wu, D. Do ethical, authentic, and servant leadership explain variance above and beyond transformational leadership? A meta-analysis. J. Manag. 2018, 44, 501-529. [CrossRef]

31. Carasco-Saul, M.; Kim, W.; Kim, T. Leadership and employee engagement: Proposing research agendas through a review of literature. Hum. Resour. Dev. Rev. 2015, 14, 38-63. [CrossRef]

32. Crawford, E.R.; Rich, B.L.; Buckman, B.; Bergeron, J. The antecedents and drivers of employee engagement. In Employee Engagement in Theory and Practice; Truss, C., Delbridge, R., Alfes, K., Shantz, A., Soane, E., Eds.; Routledge: London, UK, 2014; pp. 57-81, ISBN 9780415657426.

33. Saks, A.M.; Gruman, J.A. What do we really know about employee engagement? Hum. Resour. Dev. Q. 2014, 25, 155-182. [CrossRef]

34. Piccolo, R.F.; Colquitt, J.A. Transformational leadership and job behaviors: The mediating role of core job characteristics. Acad. Manag. J. 2006, 49, 327-340. [CrossRef]

35. Kurtessis, J.N.; Eisenberger, R.; Ford, M.T.; Buffardi, L.C.; Stewart, K.A.; Adis, C.S. Perceived organizational support: A meta-analytic evaluation of organizational support theory. J. Manag. 2017, 43, 1854-1884. [CrossRef]

36. Eisenberger, R.; Huntington, R.; Hutchison, S.; Sowa, D. Perceived organizational support. J. Appl. Psychol. 1986, 71, 500-507. [CrossRef]

37. Shamir, B.; House, R.J.; Arthur, M.B. The motivational effects of charismatic leadership: A self-concept based theory. Organ. Sci. 1993, 4, 577-594. [CrossRef]

38. Morgeson, F.P.; Humphrey, S.E. The work design questionnaire (WDQ): Developing and validating a comprehensive measure for assessing job design and the nature of work. J. Appl. Pychol. 2006, 91, 1321-1339. [CrossRef] [PubMed] 
39. Morgeson, F.P.; Campion, M.A. Work design. In Handbook of Psychology: Industrial and Organizational Psychology; Borman, W.C., Ilgen, D.R., Klimoski, R.J., Eds.; Wiley Online Library: Hoboken, NJ, USA, 2003; pp. 423-452, ISBN 9780471666745.

40. Allan, B.A. Task significance and meaningful work: A longitudinal study. J. Vocat. Behav. 2017, 102, 174-182. [CrossRef]

41. Grant, A.M. The significance of task significance: Job performance effects, relational mechanisms, and boundary conditions. J. Appl. Psychol. 2008, 93, 108-124. [CrossRef] [PubMed]

42. Goštautaitè, B.; Bučiūnienè, I. Work engagement during life-span: The role of interaction outside the organization and task significance. J. Vocat. Behav. 2015, 89, 109-119. [CrossRef]

43. Shantz, A.; Alfes, K.; Truss, C.; Soane, E. The role of employee engagement in the relationship between job design and task performance, citizenship and deviant behaviours. Int. J. Hum. Resour. Manag. 2013, 24, 2608-2627. [CrossRef]

44. Purvanova, R.K.; Bono, J.E.; Dzieweczynski, J. Transformational leadership, job characteristics, and organizational citizenship performance. Hum. Perform. 2006, 19, 1-22. [CrossRef]

45. Wang, X.; Ma, L.; Zhang, M. Transformational leadership and agency workers' organizational commitment: The mediating effect of organizational justice and job characteristics. Soc. Behav. Pers. 2014, 42, 25-36. [CrossRef]

46. Frazier, M.L.; Fainshmidt, S.; Klinger, R.L.; Pezeshkan, A.; Vracheva, V. Psychological safety: A Meta-Analytic review and extension. Pers. Psychol. 2017, 70, 113-165. [CrossRef]

47. Eisenberger, R.; Stinglhamber, F. Perceived Organizational Support: Fostering Enthusiastic and Productive Employees; American Psychological Association: Washington, DC, USA, 2011; ISBN 9781433809330.

48. Brunetto, Y.; Shacklock, K.; Teo, S.; Farr-Wharton, R. The impact of management on the engagement and well-being of high emotional labour employees. Int. J. Hum. Resour. Manag. 2014, 25, 2345-2363. [CrossRef]

49. Zhong, L.; Wayne, S.J.; Liden, R.C. Job engagement, perceived organizational support, high-performance human resource practices, and cultural value orientations: A cross-level investigation. J. Organ. Behav. 2016, 37, 823-844. [CrossRef]

50. Judge, T.A.; Erez, A.; Bono, J.E.; Thoresen, C.J. The core self-evaluations scale: Development of a measure. Pers. Psychol. 2003, 56, 303-331. [CrossRef]

51. Van Knippenberg, D.; van Knippenberg, B.; De Cremer, D.; Hogg, M.A. Leadership, self, and identity: A review and research agenda. Leadersh. Q. 2004, 15, 825-856. [CrossRef]

52. Zhou, F.; Wu, Y.J. How humble leadership fosters employee innovation behavior: A two-way perspective on the leader-employee interaction. Leadersh. Org. Dev. J. 2018, 39, 375-387. [CrossRef]

53. Messersmith, J.G.; Guthrie, J.P. High performance work systems in emergent organizations: Implications for firm performance. Hum. Resour. Manag. 2010, 49, 241-264. [CrossRef]

54. European Comission. Annual Report on European SMEs 2013-2014-A Partial and Fragile Recovery-EUbusiness; European Commission: Brussels, Belgium, 2014.

55. Desmarchelier, B.; Djellal, F.; Gallouj, F. Knowledge intensive business services and long term growth. Struct. Chang. Econ. Dyn. 2013, 25, 188-205. [CrossRef]

56. Vence-Deza, X.; González-López, M. Regional concentration of the knowledge-based economy in the EU: Towards a renewed oligocentric model? Eur. Plan. Stud. 2008, 16, 557-578. [CrossRef]

57. May, D.R.; Gilson, R.L.; Harter, L.M. The psychological conditions of meaningfulness, safety and availability and the engagement of the human spirit at work. J. Occup. Organ. Psychol. 2004, 77, 11-37. [CrossRef]

58. Grant, A.M. Relational job design and the motivation to make a prosocial difference. Acad. Manag. Rev. 2007, 32, 393-417. [CrossRef]

59. Christian, M.S.; Garza, A.S.; Slaughter, J.E. Work engagement: A quantitative review and test of its relations with task and contextual performance. Pers. Psychol. 2011, 64, 89-136. [CrossRef]

60. Cleavenger, D.J.; Munyon, T.P. It's how you frame it: Transformational leadership and the meaning of work. Bus. Horiz. 2013, 56, 351-360. [CrossRef]

61. Salancik, G.R.; Pfeffer, J. A social information processing approach to job attitudes and task design. Adm. Sci. Q. 1978, 23, 224-253. [CrossRef] [PubMed]

62. Bass, B.M. Leadership and Performance Beyond Expectations, 1st ed.; Free Press: New York, NY, USA, 1985; p. 256, ISBN 0029018102. 
63. Gözükara, İ.; Şimşek, O.F. Linking transformational leadership to work engagement and the mediator effect of job autonomy: A study in a turkish private non-profit university. Procedia Soc. Behav. Sci. 2015, 195, 963-971. [CrossRef]

64. Edmondson, A. Psychological safety and learning behavior in work teams. Adm. Sci. Q. 1999, 44, 350-383. [CrossRef]

65. Eisenberger, R.; Fasolo, P.; Davis-LaMastro, V. Perceived organizational support and employee diligence, commitment, and innovation. J. Appl. Psychol. 1990, 75, 51-59. [CrossRef]

66. Kahn, W.A. The essence of engagement: Lessons from the field. In Handbook of Employee Engagement.Perspectives, Issues, Research, and Practice; Albrecht, S.L., Ed.; Edward Elgar Publishing, Inc.: Cheltenham, UK; Northampton, MA, USA, 2010; pp. 20-30, ISBN 9781849809504.

67. Blau, P. Power and Exchange in Social Life; John Wiley \& Sons: New York, NY, USA, 1964; p. 352, ISBN 9780471080305.

68. Saks, A.M. Antecedents and consequences of employee engagement. J. Manag. Psychol. 2006, 21, 600-619. [CrossRef]

69. Eisenberger, R.; Stinglhamer, F.; Vandenberghe, C.; Sucharski, I.L.; Rhoades, L. Perceived supervisor support: Contributions to perceived organizational support and employee retention. J. Appl. Psychol. 2002, 87, 565-573. [CrossRef] [PubMed]

70. Carless, S.A.; Wearing, A.J.; Mann, L. A short measure of transformational leadership. J. Bus. Psychol. 2000, 14, 389-405. [CrossRef]

71. Judge, T.A.; Hurst, C. Capitalizing on one's advantages: Role of core self-evaluations. J. Appl. Psychol. 2007, 92, 1212-1227. [CrossRef] [PubMed]

72. Chang, C.; Ferris, D.L.; Johnson, R.E.; Rosen, C.C.; Tan, J.A. Core self-evaluations: A review and evaluation of the literature. J. Manag. 2012, 38, 81-128. [CrossRef]

73. Ferris, D.L.; Johnson, R.E.; Rosen, C.C.; Djurdjevic, E.; Chang, C.D.; Tan, J.A. When is success not satisfying? integrating regulatory focus and approach/avoidance motivation theories to explain the relation between core self-evaluation and job satisfaction. J. Appl. Psychol. 2013, 98, 342-353. [CrossRef] [PubMed]

74. Aryee, S.; Walumbwa, F.O.; Mondejar, R.; Chu, C.W.L. Core self-evaluations and employee voice behavior: Test of a dual-motivational pathway. J. Manag. 2017, 43, 946-966. [CrossRef]

75. Chiang, Y.; Hsu, C.; Hung, K. Core self-evaluation and workplace creativity. J. Bus. Res. 2014, 67, $1405-1413$. [CrossRef]

76. Karatepe, O.M.; Demir, E. Linking core self-evaluations and work engagement to work-family facilitation: A study in the hotel industry. Int. J. Contemp. Hosp. Manag. 2014, 26, 307-323. [CrossRef]

77. Lee, J.; Ok, C. Drivers of work engagement: An examination of core self-evaluations and psychological climate among hotel employees. Int. J. Hosp. Manag. 2015, 44, 84-98. [CrossRef]

78. De Cremer, D.A.; van Knippenberg, B.M.; van Knippenberg, D.; Mullenders, D.; Stinglhamber, F. Rewarding leadership and fair procedures as determinants of self-esteem. J. Appl. Psychol. 2005, 90, 3-12. [CrossRef] [PubMed]

79. Kark, R.; Shamir, B.; Chen, G. The two faces of transformational leadership: Empowerment and dependency. J. Appl. Psychol. 2003, 88, 246-255. [CrossRef] [PubMed]

80. Liao, H.; Chuang, A. Transforming service employees and climate: A multilevel, multisource examination of transformational leadership in building long-term service relationships. J. Appl. Psychol. 2007, 92, 1006-1019. [CrossRef] [PubMed]

81. Salanova, M.; Lorente, L.; Chambel, M.J.; Martínez, I.M. Linking transformational leadership to nurses' extra-role performance: The mediating role of self-efficacy and work engagement. J. Adv. Nurs. 2011, 67, 2256-2266. [CrossRef] [PubMed]

82. Xanthopoulou, D.; Bakker, A.B.; Demerouti, E.; Schaufeli, W.B. The role of personal resources in the job demands-resources model. Int. J. Stress Manag. 2007, 14, 121-141. [CrossRef]

83. Karatepe, O.M.; Nejadi, S. Do core self-evaluations mediate the effect of coworker support on work engagement? A study of hotel employees in iran. J. Hosp. Tour. Manag. 2010, 17, 62-71. [CrossRef]

84. Nguyen, N.; Borteyrou, X. Core self-evaluations as a mediator of the relationship between person-environment fit and job satisfaction among laboratory technicians. Pers. Individ. Differ. 2016, 99, 89-93. [CrossRef] 
85. Liu, W.; Li, Z.; Ling, Y.; Cai, T. Core self-evaluations and coping styles as mediators between social support and well-being. Pers. Individ. Differ. 2016, 88, 35-39. [CrossRef]

86. Brislin, R.W. Translation and content analysis of oral and written materials. In Handbook of Cross-Cultural Psychology: Methodology; Triandis, H.C., Berry, J.W., Eds.; Allyn \& Bacon: Boston, MA, USA, 1980; pp. 389-444, ISBN 9780205064984.

87. Fletcher, L. How can personal development lead to increased engagement? The roles of meaningfulness and perceived line manager relations. Int. J. Hum. Resour. Manag. 2016, 1-24. [CrossRef]

88. Little, T.D.; Cunningham, W.A.; Shahar, G.; Widaman, K.F. To parcel or not to parcel: Exploring the question, weighing the merits. Struct. Equ. Model. 2002, 9, 151-173. [CrossRef]

89. Cohen, J. Statistical Power Analysis for the Behavioral Sciences, 2nd ed.; Erlbaum Associates: Hillsdale, NJ, USA, 1988; p. 567, ISBN 9780805802832.

90. Law, K.S.; Wong, C.; Mobley, W.M. Toward A taxonomy of multidimensional constructs. Acad. Manag. Rev. 1998, 23, 741-755. [CrossRef]

91. Hair, J.F.; Black, W.C.; Babin, B.; Anderson, R. Multivariate Data Analysis, 7th ed.; Prentice Hall: Englewood Cliffs, NJ, USA, 2010; p. 816, ISBN 9780138132631.

92. Podsakoff, P.M.; MacKenzie, S.B.; Lee, J.; Podsakoff, N.P. Common method biases in behavioral research: A critical review of the literature and recommended remedies. J. Appl. Psychol. 2003, 88, 879-903. [CrossRef] [PubMed]

93. Lee, S.; Shin, Y.; Baek, S. Task characteristics and work engagement: Exploring effects of role ambiguity and ICT presenteeism. Sustainability 2017, 9, 1855. [CrossRef]

94. Lyons, J.B.; Schneider, T.R. The effects of leadership style on stress outcomes. Leadersh. Q. 2009, 20, 737-748. [CrossRef]

95. Messersmith, J.G.; Wales, W.J. Entrepreneurial orientation and performance in young firms: The role of human resource management. Int. Small Bus. J. 2013, 31, 115-136. [CrossRef]

96. Wegman, L.A.; Hoffman, B.J.; Carter, N.T.; Twenge, J.M.; Guenole, N. Placing job characteristics in context: Cross-temporal meta-analysis of changes in job characteristics since 1975. J. Manag. 2018, 44, 352-386. [CrossRef]

97. Rauch, A.; Hatak, I. A meta-analysis of different HR-enhancing practices and performance of small and medium sized firms. J. Bus. Ventur. 2016, 31, 485-504. [CrossRef]

98. Turner, N.; Barling, J.; Zacharatos, A. Positive psychology at work. In Handbook of Positive Psychology; Snyder, C.R., Lopez, S., Eds.; Oxford University Press: Oxford, UK, 2002; pp. 715-728, ISBN 9780195135336.

99. Hobfoll, S.E. Conservation of resources. A new attempt at conceptualizing stress. Am. Psychol. 1989, 44, 513-524. [CrossRef] [PubMed]

100. Halbesleben, J.R.B.; Neveu, J.; Paustian-Underdahl, S.C.; Westman, M. Getting to the "COR". J. Manag. 2014, 40, 1334-1364. [CrossRef]

101. Antonakis, J.; Fenley, M.; Liechti, S. Can charisma be taught? Tests of two interventions. Acad. Manag. Learn. Educ. 2011, 10, 374-396. [CrossRef]

102. Barling, J.; Weber, T.; Kelloway, E.K. Effects of transformational leadership training on attitudinal and financial outcomes. J. Appl. Psychol. 1996, 81, 827-832. [CrossRef]

103. Spector, P.E. Method variance in organizational research: Truth or urban legend? Organ. Res. Methods 2006, 9, 221-232. [CrossRef]

104. Zhang, H.; Kwan, H.K.; Zhang, X.; Wu, L. High core self-evaluators maintain creativity: A motivational model of abusive supervision. J. Manag. 2014, 40, 1151-1174. [CrossRef]

(C) 2018 by the authors. Licensee MDPI, Basel, Switzerland. This article is an open access article distributed under the terms and conditions of the Creative Commons Attribution (CC BY) license (http:// creativecommons.org/licenses/by/4.0/). 